\title{
Comparative Study of Conventional and Zero-joint Edgebanding
}

\author{
Mária Réka ANTAL ${ }^{\mathrm{a}}$ - Levente DÉNES ${ }^{\mathrm{ab}}$ - Zsigmond András VAS ${ }^{\mathrm{a}}-$ \\ András POLGÁR ${ }^{\mathrm{c}^{*}}$ \\ ${ }^{a}$ Institute of Wood Based Products and Technologies, Simonyi Károly Faculty of Engineering, \\ Wood Sciences and Applied Art, University of Sopron, Sopron, Hungary \\ b Transylvanian Furniture Cluster, Cluj-Napoca, Romania \\ ${ }^{c}$ Department of Environmental Protection, Institute of Environmental and Earth Sciences, \\ Faculty of Forestry, University of Sopron, Sopron, Hungary
}

\begin{abstract}
Edgebanding affects both the visual appearance and edge protection of wood-based panels. In order for edgebanding to provide the desired protection, it must adhere strongly to the entire surface of the panel edges and maintain this adhesion throughout the life of the product. The present research compares conventional and so-called zero-joint edgebandings in terms of water and steam resistance, and examines the environmental impacts of edgebanding technologies using Life Cycle Assessment (LCA). In-line with our hypothesis, our test results showed that corners are the critical points of edgebanded furniture fronts, especially when exposed to moisture. Due to high variations in measurements, there is no significant difference between the two edgebanding methods at the beginning. However, differences become more significant after longer treatment times. These differences amount to two quality categories after 6 hours and three quality categories after 12 and 24 hours. The edgebanded fronts exposed to water for less than 30 minutes experience no significant deteriorations with any of the edgebanding methods. In the case of steam resistance, zero-joint edgebanding provides better protection, especially after the second and third treatment cycle. We can state that the surplus costs of zero-joint technology are 1.45 times greater than costs associated with conventional technology. Both show the considerable costs of edging materials, chipboard, and electrical energy. The applied environmental life cycle assessment (LCA) method corresponds to the requirements of ISO 14040:2006 and ISO 14044:2006 standards. We built up the environmental inventory and the life cycle model of the manufacturing technology using the GaBi Professional LCA software. In the impact assessment, we analysed the specific environmental impact categories of the differing production processes by technology according to the operation order of the manufacturing technology. In relation to traditional and the zero-joint edging technologies, according to all impact assessment methods, the life-cycle contribution rate was uniformly $47 \%$ traditional $-53 \%$ zero-joint by impact category. The higher indicator values of the zero-joint method are due to larger edge material consumption and higher energy demand. Zero-joint technology appears to avoid the application of conventional hot melt adhesives, but replacing these adhesives does not necessarily result in better environmental indicators. Nevertheless, zero-joint egdebanding does not just improve aesthetic appearance but also exceeds the durability provided by conventional edgebanding technology.
\end{abstract}

edgebanding / resistance to water and steam / environmental impact / LCA

\footnotetext{
* Corresponding author: polgar.andras@uni-sopron.hu; H-9400 SOPRON, Bajcsy-Zs. u. 4, Hungary
} 
Kivonat - Hagyományos és fugamentes élzárás összehasonlító vizsgálata. A faalapú lemezek élzárása nemcsak esztétikailag, hanem az élek védelme szempontjából is fontos. Ahhoz, hogy az élzárás a kívánt védelmet nyújtsa erősen kell tapadnia a lemezek éleinek teljes felületéhez, és ezt a tapadást meg kell őriznie a termék teljes életciklusa alatt. Jelen kutatás a hagyományos és az ún. nullfugás élzárásokat hasonlítja össze a vízzel és gőzzel szembeni ellenállás szempontjából, valamint az élzárási technológiák környezeti hatásait vizsgálja. A vizsgálati eredmények azt mutatják, hogy a hipotézisünknek megfelelően a sarkok a kritikus pontok, a víz és gőz behatolása itt a leggyorsabb. A mérési adatok nagy szórása miatt a vízzel szembeni ellenállás esetén a két élzárási technológia között nincs szignifikáns különbség, azonban a 6 órás kitettség után két, a 12 és 24 órás kitettség után pedig három minőségi osztálykülönbség tapasztalható. Ha a víz csak maximum 30 percig érintkezik az éllel, nem tapasztalhatók elváltozások egyik élzárási módszernél sem. A gőzzel szembeni ellenállás esetén a nullfugás élzárás jobb védelmet nyújt különösen a második és harmadik gőzölési ciklus után. A kutatás során elvégeztük az életciklus költségszámítást is: a nullfugás technológia 1,45-szörös költségtöbbletet mutatott a hagyományoshoz képest. Nagyságrendileg mindkét esetben az élzáró anyag, a forgácslap és az elektromos energia költségei voltak jelentősek. A környezeti életciklus elemzés (LCA) során az ISO 14040-44:2006 szabványok alapján kizárólag az élzárási alternatívák müveleteit vizsgáltuk. Szoftveres támogatással felépítettük a gyártástechnológiák környezeti leltáradatbázisát és LCA modelljét. A hatásértékelés során technológiánként elemeztük a gyártási folyamatok jellemző környezeti hatáskategóriáit. A hagyományos és nullfugás élzárási technológiát illetően hatásértékelési módszerenként egységesen $47 \%$ hagyományos - 53\% nullfugás arány volt tapasztalható az életciklus hozzájárulásban hatáskategóriánként. A nullfugás eljárás magasabb értékei a nagyobb mennyiségü felhasznált élanyagnak és a nagyobb energiaigénynek tudhatók be. A nullfugás technológia a hagyományos ragasztóanyag alkalmazását mellőzi, ám ennek kiváltása nem eredményezett kedvezőbb környezeti mutatókat. Az élzárások esetén életciklus elemzéssel vizsgált környezeti hatásokat nemcsak az alkalmazott gyártástechnológiák jellemzői befolyásolják, hanem emellett meghatározó szerepe van az élzárt termék igénybevételekkel szembeni tartósságának is, amely az élzárási alternatíva sajátossága.

élzárás / vízzel és gőzzel szembeni ellenállás / környzeti hatás / LCA

\section{INTRODUCTION}

Wood and wood-based materials are a renewable resource and are considered 'environmentally friendly' compared to other materials (Lippke et al. 2004). Wood product manufacturing results in lower emissions than the manufacturing of other materials (Lippke et al. 2019).

The furniture industry has been increasing its use of particleboard over the past few decades. Many studies support the main importance of edging as a mandatory technological step for protecting sides of wood composite panels such as particleboard (Jivkov 2002; Tankut \& Tankut 2010; Saçli 2015; Merdzhanov 2018).

Different technologies are currently employed for edgebanding. Gluing edgebands, which has become a key technology in furniture production, is completed through a conventional bonding process: hot melt glues are applied using rollers in edgebanding woodworking machines (Rechner et al. 2009). Technological modernization has led to the quick spread of innovative processes in furniture manufacturing. One such innovation is zero-joint edgebanding, which is considered an important technological operation in the wood industry. The main differences between the two edgebanding technologies are aesthetical appearance and adhesive spreading. The zero joint glue line is almost invisible due to the coextruded functional layer. Moreover, an additional bonding agent is unnecessary (Figure 1). Consequently, the environmental significance of the method is beyond question.

In edgebanding that incorporates laser technology, laser radiation melts a predetermined layer of the edging material. According to Rechner et al. (2009), laser technology for the edgebanding process in furniture manufacturing provides the same strength as conventional gluing, all without the adhesive joints that affect visual appearance. The transition between the 
edgeband and the board surface provides a flawless appearance to the human eye. At the same time, the impact of external influences (like water or dirt) is reduced to a minimum. This increases the resistance of the adhesive bond to ageing (Rechner et al. 2009).

According to Tankut and Tankut (2010), the purpose of edgebanding is to suppress the absorption of water and humidity and provide an aesthetic finish for all decorative surfaces.

Edgebanding has two main functions: to cover the aesthetically unfavorable core panels like particleboard, fiberboard, etc., and to protect these panels from mechanical and physical impacts (Molnárné 2002). To fulfill these requirements, edgebanding materials (coiled foils from polyvinyl chloride [PVC], acrylonitrile butadiene styrene [ABS], polypropylene [PP], polymethylmethacrylate [PMMA], or strips from solid wood) must be perfectly bonded to the panel edges without voids or loose parts, leveled to the thickness of the panels, and trimmed to the desired dimensions and shapes. Several factors influence the durability of the adhesion line between edgebanding materials and panels. Among these we find the resistance to moisture, which affects edgebanding in two main forms i.e., liquid and vapor.

In addition to durability, the quality (conformity) factors of the product include other characteristics, such as aesthetics or environmental impacts. Life-Cycle Assessment (LCA) is the most suitable method for determining the environmental impacts of a product. According to Fava et al. (1994), the development of the LCA methodology has helped to quantify and provide information about products where environmental qualities were lacking.
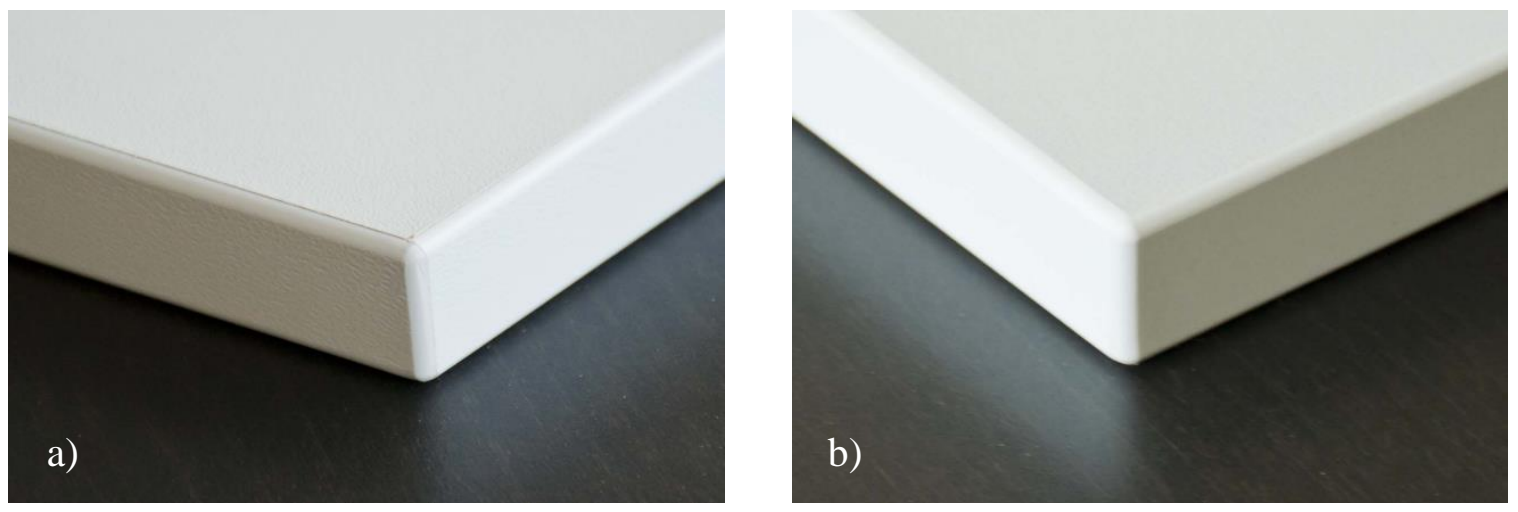

Figure 1. Aesthetic comparison of conventional (a) and zero-joint (b) ABS edgebanding

The first main goal of this research was to examine how moisture affects the durability and aesthetics of edgebanded panels. Moisture came into contact with the surface in two forms: cold liquid and hot steam. Conventional (EVA) and zero-joint technologies were used to determine the effect of edgebanding type on thickness swelling. The second goal of our study was to use the LCA method to determine and compare the environmental impacts of conventional and the zero-joint edgebanding technologies in the wood industry. Durability affects the environmental impacts additionally. If the edgebanding is more durable, the edgebanded panel is favourable in terms of environmental impacts.

\section{MATERIALS AND METHODS}

Hungarian furniture manufacturers most frequently use $18 \mathrm{~mm}$-thick laminated particleboards; hence, these were selected for both the durability and environmental studies. Acrylonitrile butadiene styrene (ABS) was the material selected for edgebanding. The edgebanding methods employed were the conventional (using hot melt adhesive EVA) and zero-joint technology methods. A Roxyl 6.0 edgebander wood machine was used for both conventional and zero-joint edgebanding. Life-Cycle Analysis (LCA) was used to determine environmental impacts. We 
used the GaBi Professional LCA software, which is the most trusted product for Life Cycle Assessment.

\subsection{Durability study}

All tests were performed according to the IOS-TM-0002 IKEA specification.

\subsubsection{Assessment of edges' resistance to water}

This test simulates the water resistance of the edgebanded furniture fronts used in locations with elevated humidity levels such as kitchens and bathrooms. Five specimens were used per edgebanding technology. The 400x300 mm edgebanded specimens were conditioned at $23 \pm 2{ }^{\circ} \mathrm{C}$ and $50 \pm 5 \%$ humidity prior to testing. Seven measuring points were selected for specimen' thickness determination: five at the edge and two at a distance of $20 \mathrm{~mm}$ from the edge. The first and last measuring points at the edge were located at the corners of the specimens, and the distance between each point was $100 \mathrm{~mm}$. Figure 2 shows the placement of the measuring points.

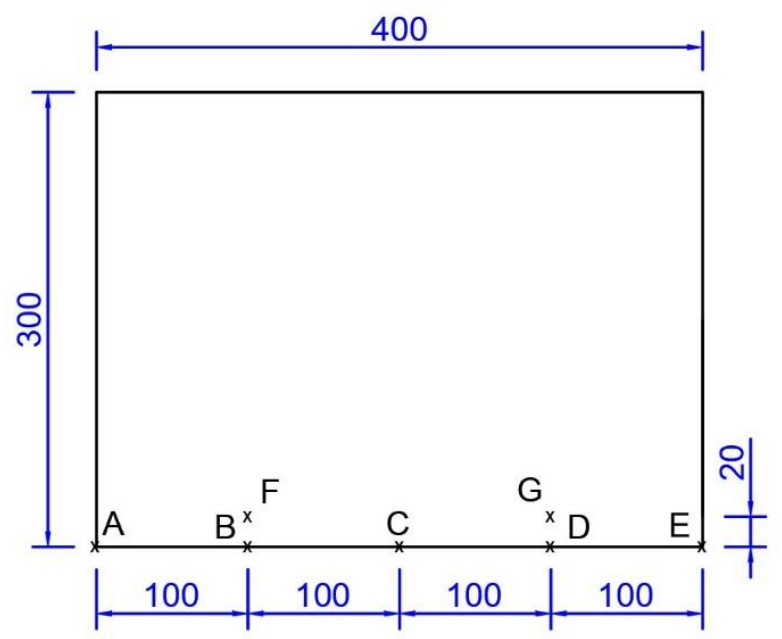

Figure 2. Measuring points of water and steam resistance

Sample thickness was determined at the measuring points to the nearest $0.01 \mathrm{~mm}$ using a digital caliper after conditioning and before the tests began. A $50 \mathrm{~mm}$-thick, open-cell polyurethane foam with a density of $20 \mathrm{~kg} / \mathrm{m}^{3}$ was placed in a flat tub equipped with spacer plates of the same height as the tub height $(50 \mathrm{~mm})$, and the tub was filled with distilled water at $23 \pm 2{ }^{\circ} \mathrm{C}$. Water level was kept constant at $12 \mathrm{~mm}$ below the upper edge of the spacers throughout the entire test period. The edgebanded specimens were placed vertically on the partition plates and exposed for the time corresponding to the test periods (Figure $3 a$ ). A total of seven test periods with the following values were used: $5 \mathrm{~min}, 30 \mathrm{~min}, 2 \mathrm{~h}, 6 \mathrm{~h}, 12 \mathrm{~h}, 24 \mathrm{~h}$, and $48 \mathrm{~h}$. The last period consisted of 24 hours of soaking and 24 hours of conditioning. After each test period, the specimen edges were wiped dry and the thickness was measured at the measurement points. After visual inspection of the edges, the thickness swelling results were evaluated on a scale of 1 to 5 as defined in the specification (Table 1). 
Table 1. Assessment criteria for water resistance (IOS 2017)

\begin{tabular}{cl}
\hline Rating & Criteria \\
\hline $\mathbf{5}$ & No visible damage can be seen; thickness swelling is less than $0.05 \mathrm{~mm}$. \\
\hline $\mathbf{4}$ & $\begin{array}{l}\text { Minor damage that does not affect function or appearance essentially is accepted. } \\
\text { The maximum thickness swelling is } 0.1 \mathrm{~mm} \text {, but without visible cracking or } \\
\text { opening between edge bands. }\end{array}$ \\
$\mathbf{3}$ & $\begin{array}{l}\text { Moderate damage with thickness swelling from } 0.1 \text { to } 0.25 \mathrm{~mm} \text {. The glue line } \\
\text { may have become soft, but there is still enough adhesive to keep the edging in } \\
\text { place. } \\
\text { The edging may loosen to mechanical strain and few narrow cracks are allowed. }\end{array}$ \\
$\mathbf{2}$ & $\begin{array}{l}\text { Significant damage with thickness swelling from } 0.25 \text { to } 1.0 \mathrm{~mm} \text {. } \\
\text { Open glued joint or partly loose edging. Several narrow cracks may appear. }\end{array}$ \\
$\mathbf{1}$ & $\begin{array}{l}\text { Severe damage: thickness swelling is over } 1 \mathrm{~mm} \text {. Loose edging, totally or partly } \\
\text { damaged surface finish. Many narrow cracks or one or more broad cracks. }\end{array}$ \\
\hline
\end{tabular}
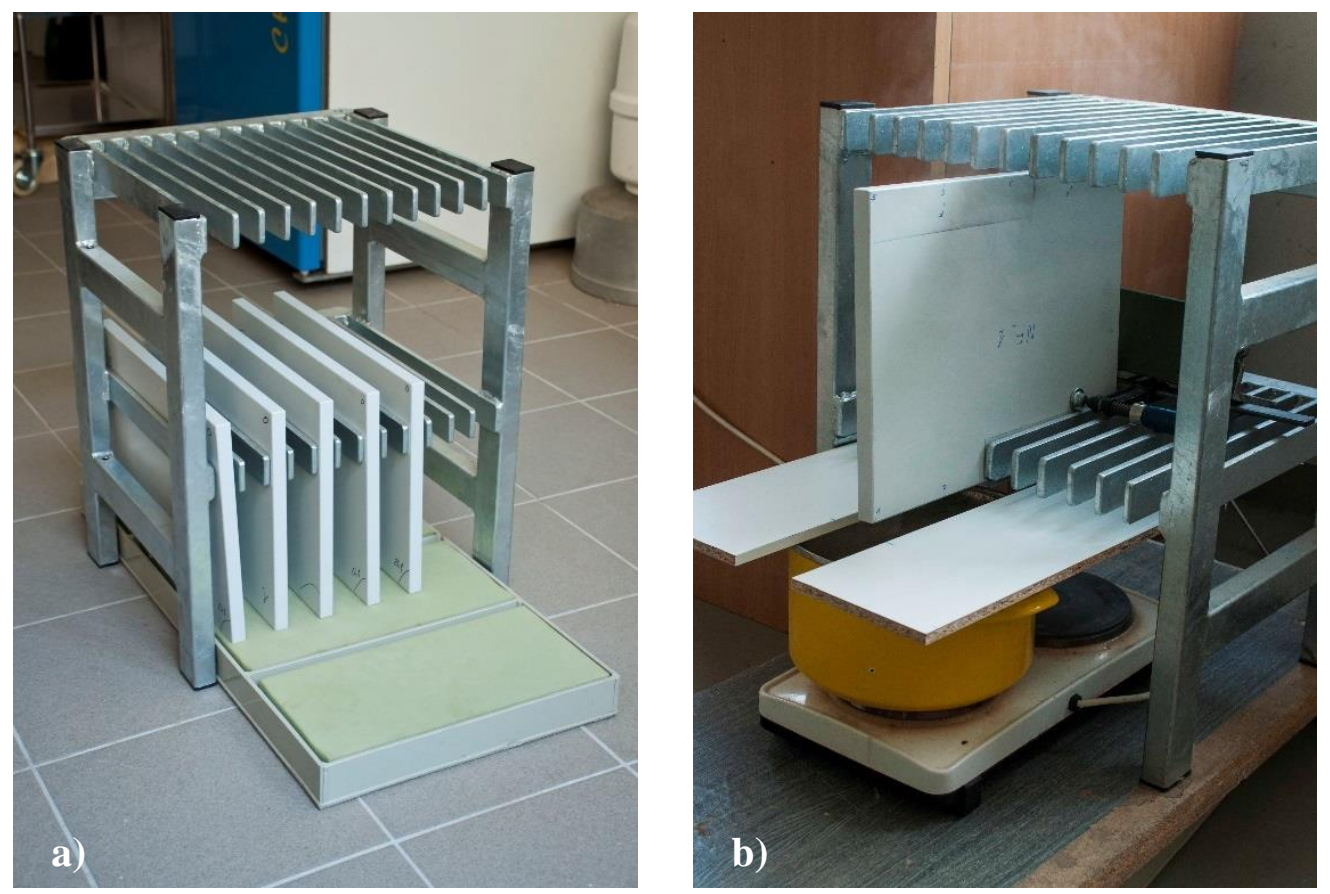

Figure 3. Determination of edge resistance to water and steam ( $a$-to water; $b$-to steam)

\subsubsection{Assessment of edges' resistance to steam}

The test method simulates the effect of steam and condensation on edgebanded furniture fronts. Edgebanded specimens with dimensions of 400x300 mm were cleaned prior to conditioning (see the test method for water resistance test) and examined for defects. Sample thickness was measured at the corner and at a distance of $100 \mathrm{~mm}$ from the corner. Specimens were mounted on the jig using a clamp with the tested edge facing downward and resting on the water-bath with the corner at a distance of $50 \mathrm{~mm}$ from bath side. The length of the exposed edge was about $150 \mathrm{~mm}$. The water bath placed beneath specimens was heated using an electric hob, with the water level set at $70 \mathrm{~mm}$ below the edge of the test samples. The water bath was covered with two panels allowing a $70 \mathrm{~mm}$ wide gap for specimens (Figure $3 \mathrm{~b}$ ). After five minutes of steam exposure and 24 hours conditioning, specimen thickness was measured at two measuring points. This cycle was repeated two more times, with the cumulated steam exposure time 
reaching 15 minutes. After each cycle, the tested edges were examined for damage. At the end of the three cycles, the tested edges were assessed according to Table 2.

Table 2. Assessment criteria for steam resistance (IOS 2017)

\begin{tabular}{cl}
\hline Rating & Criteria \\
$\mathbf{5}$ & No visible damage. \\
$\mathbf{4}$ & Minor change: slight discoloration, rough surface, minor gloss change. \\
$\mathbf{3}$ & $\begin{array}{l}\text { Moderate change: minor blistering, small cracks and opening (maximum } 1 \mathrm{~mm}), \\
\text { visible/noticeable thickness swelling. }\end{array}$ \\
$\mathbf{2}$ & $\begin{array}{l}\text { Significant change: opening of maximum } 2 \mathrm{~mm} \text {, large cracks, } \\
\text { the edge band is partly loose. }\end{array}$ \\
$\mathbf{1}$ & $\begin{array}{l}\text { Severe change: large opening }(>2 \mathrm{~mm}), \text { large cracks along/across the edge, } \\
\text { edge band completely detached. }\end{array}$ \\
\hline
\end{tabular}

\subsection{Environmental study}

The objective of the environmental study was to perform a comparative life cycle analysis of conventional and zero-joint edgebanding technologies. The study refers of $3.5 \mathrm{~m}^{3}$ quantity chipboard, edgebanded with two different types of ABS materials for conventional and zerojoint edging technologies. The input and output data for this study are presented in Table 4. The data sources stem from Hungarian manufacturing data, our own data, expert estimations, and published data. Reference period: 2016.

The applied environmental life cycle assessment ( $L C A)$ method corresponds to the requirements of ISO 14040:2006 (ISO 2006a) and ISO 14044:2006 (ISO 2006b) standards.

The environmental life cycle assessment (LCA) method plays an important role in the analysis of environmental impacts. Life cycle assessment enables the determination of the sustainability and environmental quality of wood products and the related manufacturing technologies.

Life-cycle methods allow for the evaluation of environmental burdens such as air and water pollution, solid waste, and ecosystem impacts (Lippke et al. 2019).

To run LCA, we examined the flow of material and energy on the input and output side during the conventional and zero-joint wood edgebanding operations. We also examined each material cost during the analysis.

We built up the environmental inventory and the life cycle model of the manufacturing technology using the GaBi Professional LCA software. In the impact assessment, we analysed the specific environmental impact categories of the differing production processes by technology according to the order of operation of the manufacturing technology. For a reliable analysis, we calculated the impact-category indicator results by using several impact assessment methods and models (CML2001, Primary energy).

Functional unit: edgebanding the chipboard elements of the specific furniture family with ABS edgebanding material

- reference flow (conventional): ABS edge material, $1006.98 \mathrm{~m}$ long, $2.00 \mathrm{~mm}$ thick, $22.65 \mathrm{~mm}$ wide

- reference flow (zero-joint): ABS edge material, $1006.98 \mathrm{~m}$ long, $2.35 \mathrm{~mm}$ thick, $23.15 \mathrm{~mm}$ wide

As regards the transport of raw materials, we considered $100 \mathrm{tkm}$ and a EURO 4 truck. In the case of electrical energy, we used the Hungarian energy mix. 
The edgebanding process steps (operational steps) of the Roxil 6.0 edgebander wood machine, which are also the LCA boundaries, comprise the following: raw materials transport - loading of banding material - chipboard surface handling - chipboard edge milling - applying glue (gluing) (omitted for zero-joint technology) - applying banding material by pressing (bonds the edge banding to the substrate) - end-cutting banding material - rough and fine trimming - edge rounding - ABS edge refining - glue scraping (omitted for zero-joint technology) - cutting grooves or rabbets (if necessary) - edge polishing using brush - edge heating for colour correction using air blower - panel transport (Kozák 2006).

\section{RESULTS AND DISCUSSION}

\subsection{Water resistance}

Specimen thicknesses were measured in the assigned points after each treatment. F-tests and Student $\mathrm{t}$-tests were employed for the statistical analysis of the data. Figure 4 presents the variation of thickness swelling in function of treatment time, edgebanding technologies, and measurement points. From the three-dimensional column diagram, we can deduce that visible changes occur only at the corners (points A and E) and at a distance of $100 \mathrm{~mm}$ from the left corner (point B). The thickness swelling at point B is remarkable only in conventional joints; there are no visible changes at zero joints. Both joint types were waterproof for 30 minutes. The first noticeable deviations occurred after two hours of exposure. The maximum thickness swelling of $1.31 \mathrm{~mm}$ was measured at the corner of the conventional joints after 24 hours of treatment. In point A (specimens' left corner) there were no statistically significant differences between conventional and zero joints. However, at a distance of $100 \mathrm{~mm}$ from the corner (point B) after 2 hours of water exposure, the conventional joints swelling was $0.112 \mathrm{~mm}$ and increased gradually with the exposure time, but the zero joints showed no changes in thickness. At the right corner (point E), the visible changes appeared just after 6 hours of exposure and the zero joints had higher swelling values than conventional joints. After 24 hours of exposure and 24 hours of conditioning, the specimens started to lose water in the conditioning phase and the thickness values began to decline; however, this change was not statistically significant.

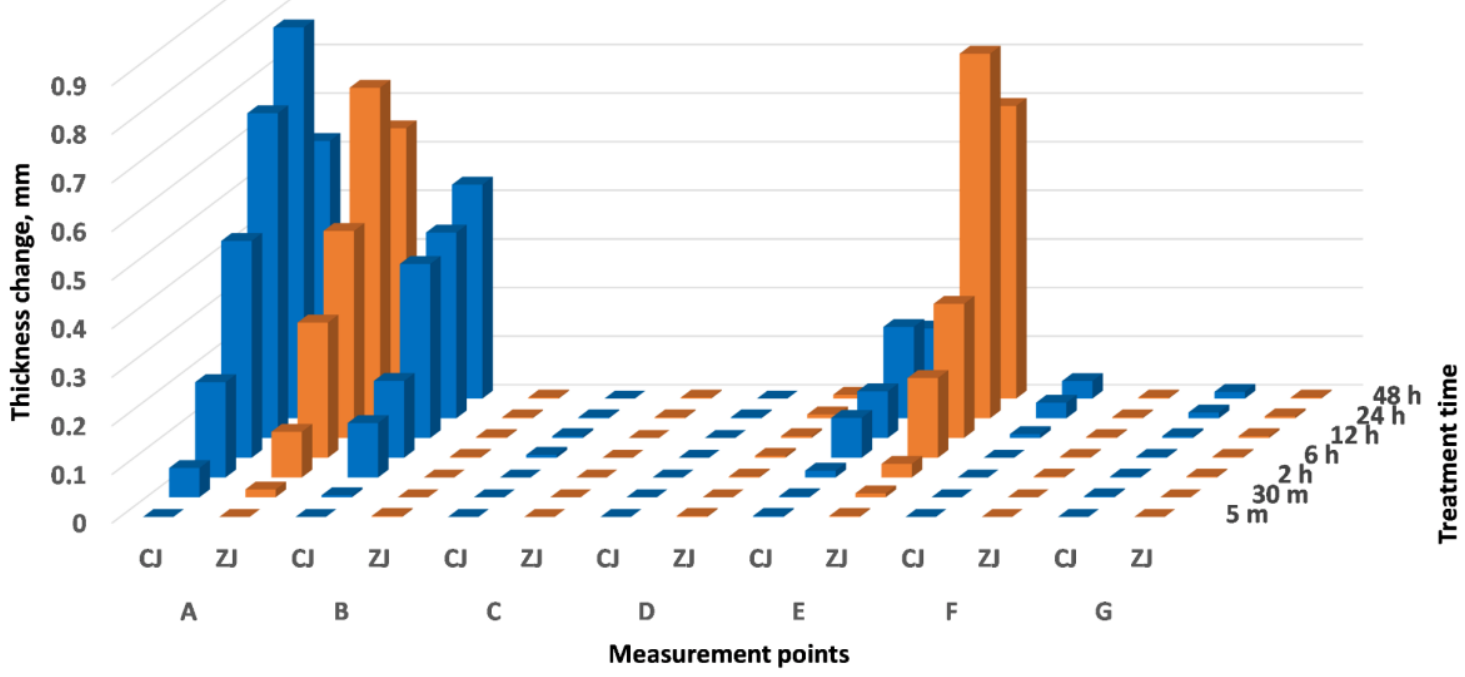

Figure 4. The average thickness swelling of specimens with conventional (CJ) and zero joints $(Z J)$ at the measurement points $(A-G)$ after different moisture exposure times 
Table 3 contains the average rating values of the measuring points in function of treatment time and joint type. The values confirm the statements related to Figure 4 . The first differences in rating values (see Table 1) between conventional and zero joints appeared after 2 hours of exposure at the left corner, and after 12 hours both joints showed significant changes, the value decreased from 5 to 2 . Rating differences between the two joint types were less accentuated at the opposite corner; however, zero joint values were worse than conventional joint values. In point $\mathrm{B}$, the conventional joint degraded gradually, but the zero joints remained intact after 2 hours of exposure. This contradiction needs to be analysed further on a larger sample to discover if it is local gluing defects or the variation is too high.

Table 3. Classification of measuring points based on the assessment criteria

\begin{tabular}{|c|c|c|c|c|c|c|c|c|c|c|c|c|c|c|}
\hline \multirow{3}{*}{$\begin{array}{c}\text { Measuring } \\
\text { points }\end{array}$} & \multicolumn{14}{|c|}{ Treatment duration } \\
\hline & \multicolumn{2}{|c|}{$5 \mathrm{~min}$} & \multicolumn{2}{|c|}{$30 \mathrm{~min}$} & \multicolumn{2}{|c|}{$2 \mathrm{~h}$} & \multicolumn{2}{|c|}{$6 h$} & \multicolumn{2}{|c|}{$12 \mathrm{~h}$} & \multicolumn{2}{|c|}{$24 \mathrm{~h}$} & \multicolumn{2}{|c|}{$48 \mathrm{~h}$} \\
\hline & $\mathrm{CJ}$ & $\mathrm{ZJ}$ & $\mathrm{CJ}$ & $\mathrm{ZJ}$ & $\mathrm{CJ}$ & $\mathrm{ZJ}$ & $\mathrm{CJ}$ & $\mathrm{ZJ}$ & CJ & $\mathrm{ZJ}$ & $\mathrm{CJ}$ & $\mathrm{ZJ}$ & $\mathrm{CJ}$ & $\mathrm{ZJ}$ \\
\hline A & 5 & 5 & 4 & 5 & 3 & 4 & 2 & 2 & 2 & 2 & 2 & 2 & 2 & 2 \\
\hline $\mathrm{B}$ & 5 & 5 & 5 & 5 & 3 & 5 & 3 & 5 & 2 & 5 & 2 & 5 & 2 & 5 \\
\hline $\mathrm{C}$ & 5 & 5 & 5 & 5 & 5 & 5 & 5 & 5 & 5 & 5 & 5 & 5 & 5 & 5 \\
\hline $\mathrm{D}$ & 5 & 5 & 5 & 5 & 5 & 5 & 5 & 5 & 5 & 5 & 5 & 5 & 5 & 5 \\
\hline $\mathrm{E}$ & 5 & 5 & 5 & 5 & 5 & 5 & 4 & 3 & 4 & 2 & 3 & 2 & 3 & 2 \\
\hline $\mathrm{F}$ & 5 & 5 & 5 & 5 & 5 & 5 & 5 & 5 & 5 & 5 & 5 & 5 & 5 & 5 \\
\hline $\mathrm{G}$ & 5 & 5 & 5 & 5 & 5 & 5 & 5 & 5 & 5 & 5 & 5 & 5 & 5 & 5 \\
\hline
\end{tabular}

\subsection{Steam resistance}

Figure 5 displays the thickness swelling values of the edgebanded specimens exposed to steaming. The thickness increases were visible after each treatment cycle, reaching a maximum of $1.75 \mathrm{~mm}$ at the corner of one of the conventionally edgebanded specimens. After 5 minutes, the differences between the two joint types were noticeable, but after 10 minutes, this difference attained $40 \%$. The corner was more affected by steaming than the edges; however, after 15 minutes of exposure the average thickness swelling of the conventional joint at a distance of $100 \mathrm{~mm}$ reached $1 \mathrm{~mm}$. This value is $80 \%$ higher than the value of the zero joint $(0.2 \mathrm{~mm})$. The measured values demonstrate that the conventional joints are more sensitive to steaming.

Statistical evaluations revealed that thickness-swelling values were significantly higher at the corner than at a distance of $100 \mathrm{~mm}$ from the corner. No significant difference appeared between the conventional and zero joint after one cycle; however, after 10 and 15 minutes of steam exposure the zero joint swelling values were considerably lower (with $39 \%$ and 37\%). A gradually increasing thickness swelling can be observed by extending the exposure time from 5 to 15 minutes. At $100 \mathrm{~mm}$ from the corner, there is a significant difference between the two joint types after 10 minutes treatment, and the conventional joint thickness increased considerably at the end of the total exposure. Figure 6 shows the effect of moisture and steam on the edgebanded samples. 


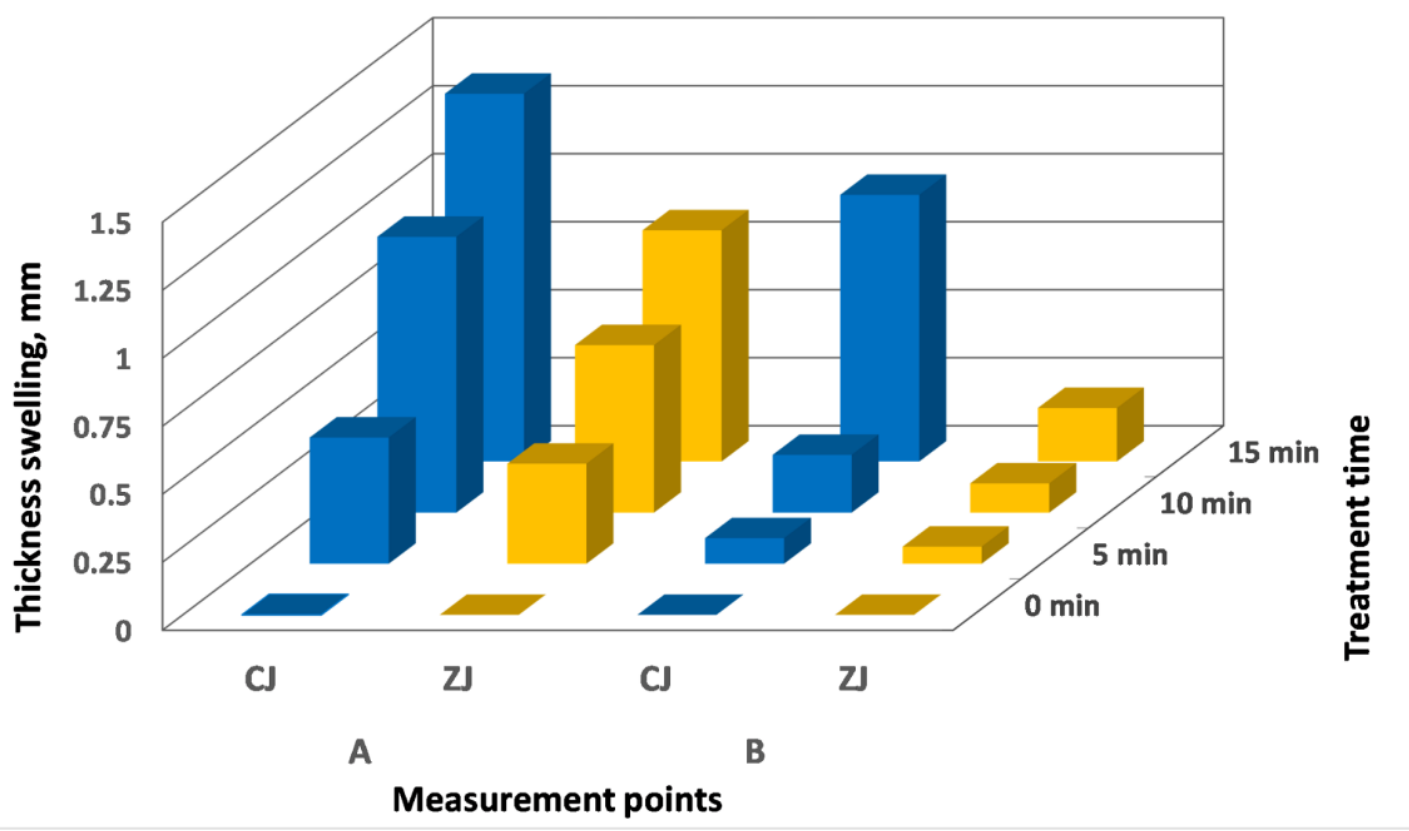

Figure 5. The average thickness swelling of specimens with conventional (CJ) and zero joints $(Z J)$, in the measurement points $(A$ and $B)$ after different steam exposure times

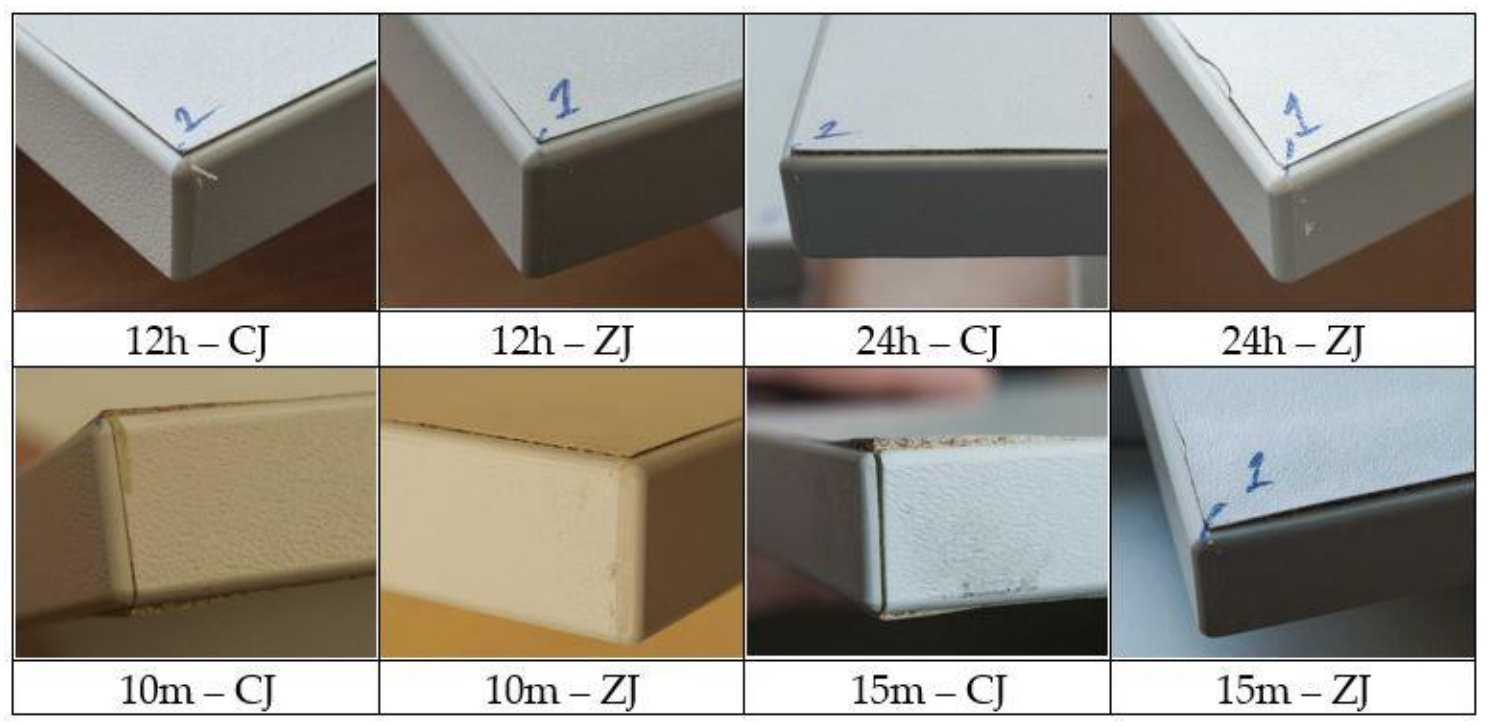

Figure 6. The effect of moisture and steam on the edgebanded samples

\subsection{Environmental impacts}

In Table 4, we collected the most important environmental inventory data, namely the inputs and outputs specific to the process. According to standard ISO 14044:2006 (ISO 2006b), the inputs could be product, material, or energy flow that enters a unit process. The output could be product, material or energy flow that leaves a unit process (products and materials include raw materials, intermediate products, co-products, and releases).

These inputs and outputs were the environmental factors (material and energy abstractions and emissions during the technology) that define the system boundaries of the analysis. The inputs and outputs were empirical data as well as data based on Hungarian manufacturing technology. These data were collected in the reference year 2016. 
Table 4. Total environmental inventory data of edgebanding technologies (our own data were collected from manufacturing technology in Hungary, reference period: 2016)

\begin{tabular}{|c|c|c|c|}
\hline \multirow{2}{*}{ Environmental inventory } & \multirow{2}{*}{ Unit } & \multicolumn{2}{|c|}{ Edgebanding } \\
\hline & & Conventional & Zero-joint \\
\hline \multicolumn{4}{|l|}{ Input } \\
\hline $\begin{array}{l}\text { Acrylonitrite-Butadiene-Styrene (ABS) edge } \\
\text { material }\end{array}$ & $\mathrm{kg}$ & 48.50 & 53.69 \\
\hline Electrical energy & $\mathrm{kWh}$ & 171.68 & 246.59 \\
\hline Treatment fluid (ethanol) & $\mathrm{ml}$ & 458.10 & 458.10 \\
\hline Chipboard $18 \mathrm{~mm}$ & $\mathrm{~kg}\left(\mathrm{~m}^{3}\right)$ & $2277.99(3.50)$ & $2277.9(3.50)$ \\
\hline $\begin{array}{l}\text { Ethylene-vinyl acetate copolymers, } \\
\text { adhesive granulate (EVA) }\end{array}$ & $\mathrm{kg}$ & 0.10 & - \\
\hline Lubricating oil & $\mathrm{kg}$ & 0.0016 & 0.0016 \\
\hline Package of adhesive (plastic) & $\mathrm{kg}$ & 0.002 & 0.002 \\
\hline Package of edging material (cardboard) & $\mathrm{kg}$ & 3.65 & 3.65 \\
\hline \multicolumn{4}{|l|}{ Output } \\
\hline $\begin{array}{l}\text { Acrylonitrite-Butadiene-Styrene (ABS) edge } \\
\text { material }\end{array}$ & $\mathrm{kg}$ & 35.42 & 39.84 \\
\hline Treatment fluid (ethanol) & $\mathrm{ml}$ & 343.56 & 343.56 \\
\hline Chipboard $18 \mathrm{~mm}$ & $\mathrm{~kg}\left(\mathrm{~m}^{3}\right)$ & $2257.44(3.47)$ & $2257.4(3.47)$ \\
\hline $\begin{array}{l}\text { Ethylene-vinyl acetate copolymers, } \\
\text { adhesive granulate (EVA) }\end{array}$ & $\mathrm{kg}$ & 0.09 & - \\
\hline Packaging waste material & $\mathrm{kg}$ & 0.011 & - \\
\hline Edge material waste & $\mathrm{kg}$ & 13.08 & 13.85 \\
\hline Chipboard waste & $\mathrm{kg}\left(\mathrm{m}^{3}\right)$ & $20.55(0.032)$ & $20.55(0.032)$ \\
\hline Treatment fluid waste & $\mathrm{ml}$ & 114.54 & 114.54 \\
\hline Package of adhesive (plastic) & $\mathrm{kg}$ & 0.002 & 0.002 \\
\hline Package of edging material (cardboard) & $\mathrm{kg}$ & 3.65 & 3.65 \\
\hline Waste oil (recycled) & $\mathrm{kg}$ & 0.0016 & 0.0016 \\
\hline
\end{tabular}

Based on the environmental inventory data, costs emerging in the examined life cycle can also be included in the life cycle costing (LCC) method. LCC analysis provides an appropriate basis for calculating the costs in the life cycle. Through this, profit can be maximized at all stages of the life cycle. One of the advantages of LCC analysis is that all investment costs and cost structures can be demonstrated. This enables a more accurate calculation, which leads to better decision making (Laáb 2021).

In the case of the environmental inventory data, we assigned the costs primarily to the inputs (the prices of the inputs come from the raw material distribution companies, July 2020 prices). According to this, the total cost of inputs for conventional edgebanding technology were HUF 792,896; while the total cost of inputs for the zero-joint edging technology were HUF 1,152,642. We can state that zero-joint technology displays a 1.45 times surplus compared to conventional technology. Both technologies showed considerable costs of the edging material, the chipboard, and the electrical energy. Concerning the input, significant differences (more than doubled value) occurred from the quantity of acrylonitrite-butadiene-styrene (ABS) edge material (in the case of $1006.98 \mathrm{~m}$, traditional: HUF 213,480, zero-joint: HUF 568,950). The costs of ABS edge material waste by technologies were the following: traditional, HUF 57,574 (27\%); zero-joint, HUF 146,768 (28\%). 
Differences in electricity consumption also arose. Zero-joint technology requires 1.44 times more energy input compared to conventional technology, which results in additional costs.

The usage of ethylene-vinyl acetate copolymers, adhesive granulate (EVA) in the conventional technology results in only HUF 226,300 extra cost compared to the zero-joint technology.

In the impact assessment process, the environmental impact categories of the specific production processes were analysed by technology according to the operational sequence of the edgebandings.

The following results in Figure 7 were based on the CML 2001 (version: April 2015) problem-oriented impact assessment method.

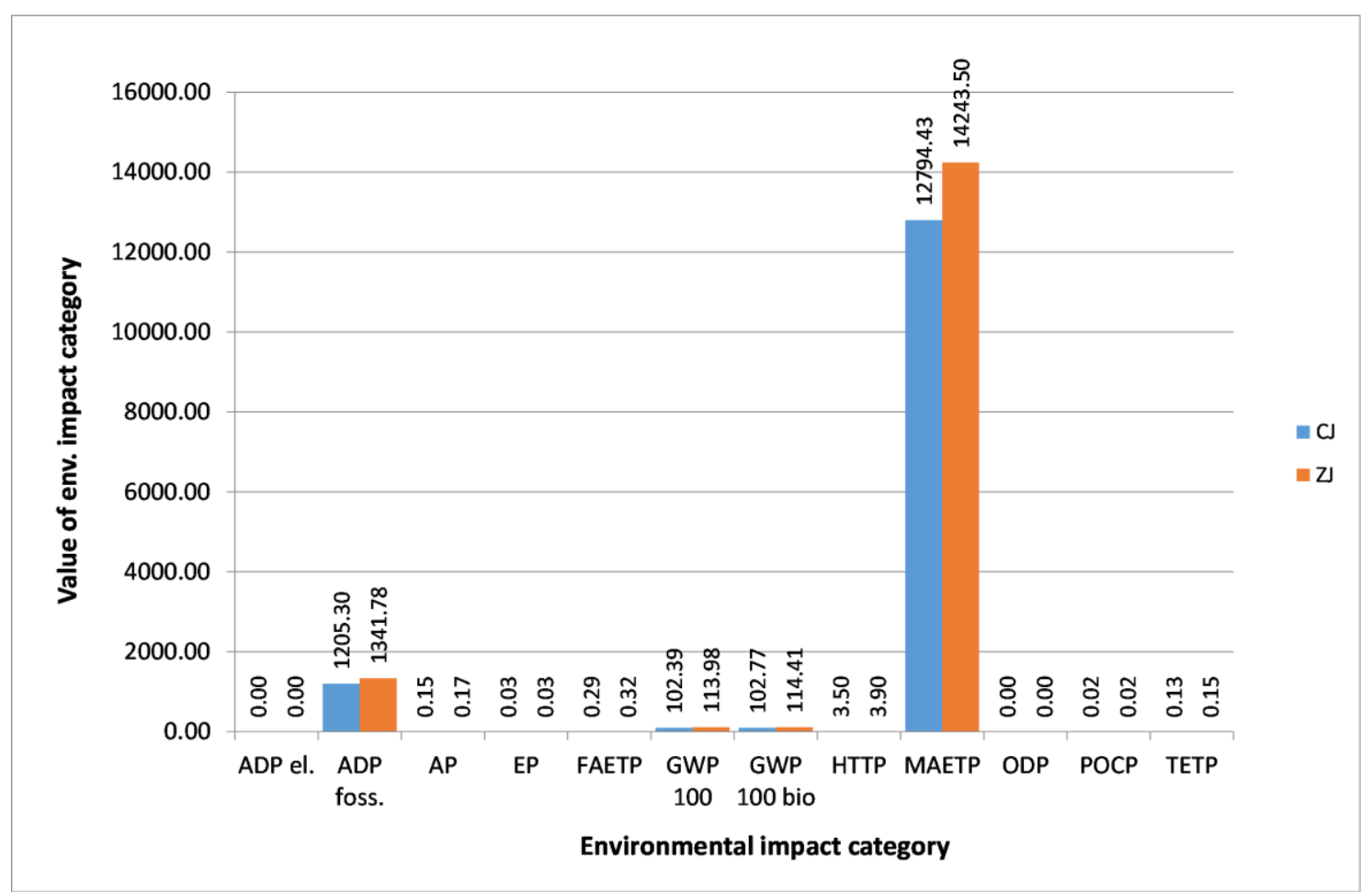

Abbreviations: Conventional (CJ) and Zero joints (ZJ) edgebanding;

ADP el. - Abiotic Depletion (ADP elements) [kg Sb-Equiv.]; ADP foss. - Abiotic Depletion (ADP fossil) [MJ]; AP - Acidification Potential (AP) [kg SO2-Equiv.]; EP - Eutrophication Potential (EP) [kg Phosphate-Equiv.]; FAETP - Freshwater Aquatic Ecotoxicity Pot. (FAETP inf.) [kg DCB-Equiv.]; GWP 100 - Global Warming Potential (GWP 100 years) [kg CO2-Equiv.]; GWP 100 bio - Global Warming Potential (GWP 100 years), excl biogenic carbon [kg CO2-Equiv.]; HTTP - Human Toxicity Potential (HTP inf.) [kg DCB-Equiv.]; MAETP - Marine Aquatic Ecotoxicity Pot. (MAETP inf.) [kg DCB-Equiv.]; ODP - Ozone Layer Depletion Potential (ODP, steady state) [kg R11-Equiv.]; POCP - Photochem. Ozone Creation Potential (POCP) [kg Ethene-Equiv.]; TETP - Terrestric Ecotoxicity Potential (TETP inf.) [kg DCB-Equiv.]

Figure 7. Environmental impacts of edgebanding technologies in the impact categories of the CML 2001 (April 2015) impact assessment methodology

The technologies had the greatest impact on Marine Aquatic Ecotoxicity Pot. (MAETP) during their entire life cycle based on the CML 2001 (April 2015) problem-oriented (focusing on midpoints) assessment method. This can be explained by the edge material consumption of the technologies and by the transport. ADP foss.-Abiotic Depletion (ADP fossil) emerged as a significant impact category. 
GWP 100-Global Warming Potential (GWP 100 years) values were negligible. The life cycle contribution evolved in the proportion of $47 \%$ conventional - 53\% zero-joint according to the impact categories.

Figure 8 displays the contribution of the different operational steps within the conventional and zero-joint edgebanding technologies to the above environmental impact categories.

Operational steps (conventional): 1) Placing and feeding the edgebanding material roll into the machine + handling of the chipboard surfaces; 2) $1 \mathrm{~mm}$ milling of chipboard edge; 3) Melting, adding EVA granulate and applying glue + pressing the edgebanding onto the workpiece edge (bonds the edge banding to the substrate); 4) End-cutting banding material; 5) Trimming excess material at the bottom and top of edges; 6) Fine trimming excess material at the bottom and top of edges; 7) Rounding of edges; 8) Scraping any surplus of glue and banding materials; 9) Milling of workpiece on the edges; 10) Polishing of the edge surface + heating the edge of the workpiece for colour correction using hot air blower; 11) Lubricant oil; 12) Raw materials transport 1 ; 13) Raw materials transport 2

Operational steps (zero-joint):1) Loading of banding material + handling of the chipboard surfaces with anti-adhesive fluid; 2) $1 \mathrm{~mm}$ milling of chipboard edge; 3) Pressing the edgebanding onto the workpiece edge (bonds the edge banding to the substrate); 4) End-cutting banding material; 5) Trimming excess material at the bottom and top of edges; 6) Fine trimming excess material at the bottom and top of edges; 7) Rounding of edges; 8) Scraping any surplus of banding materials; 9) Milling of workpiece on the edges; 10) Polishing of the edge surface + heating the edge of the workpiece for colour correction using hot air blower; 11) Lubricant oil; 12) Raw materials transport 1; 13) Raw materials transport 2

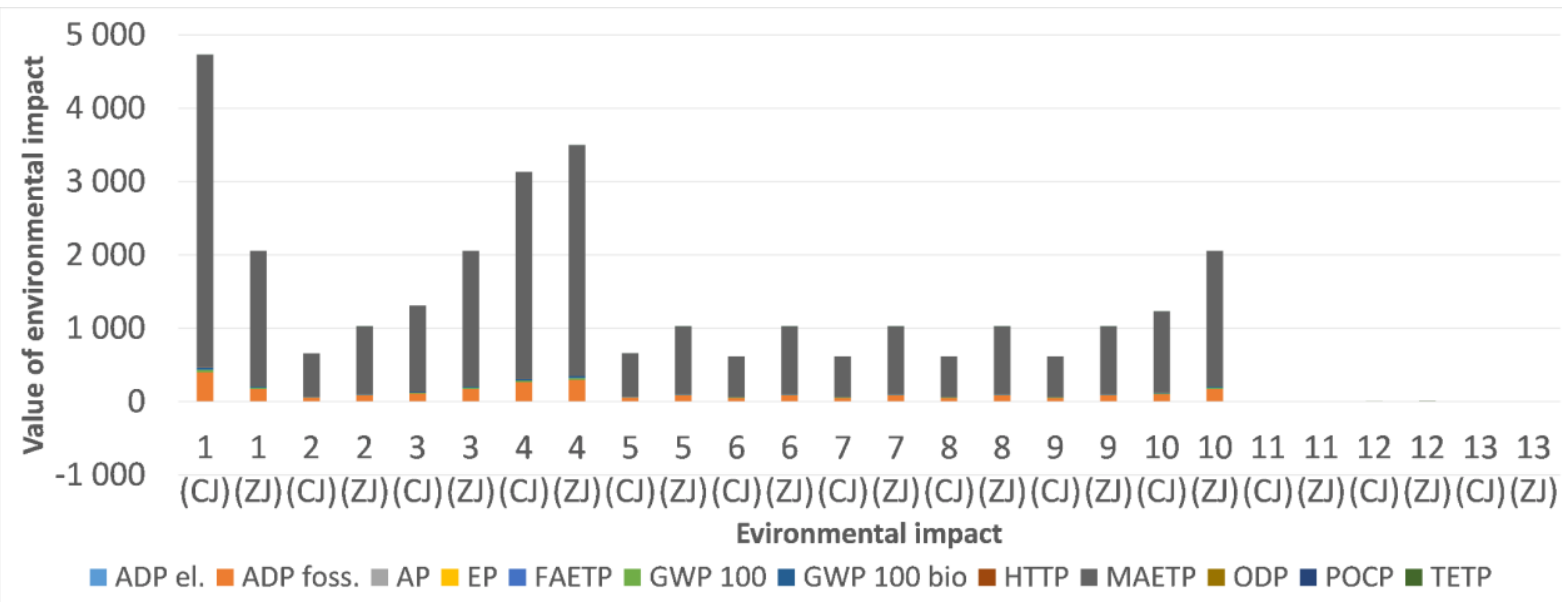

Abbreviations: Conventional (CJ) and Zero joints (ZJ) edgebanding;

ADP el. - Abiotic Depletion (ADP elements) [kg Sb-Equiv.]; ADP foss. - Abiotic Depletion (ADP fossil) [MJ]; AP - Acidification Potential (AP) [kg SO2-Equiv.]; EP - Eutrophication Potential (EP) [kg Phosphate-Equiv.]; FAETP - Freshwater Aquatic Ecotoxicity Pot. (FAETP inf.) [kg DCB-Equiv.]; GWP 100 - Global Warming Potential (GWP 100 years) [kg CO2-Equiv.]; GWP 100 bio - Global Warming Potential (GWP 100 years), excl biogenic carbon [kg CO2-Equiv.]; HTTP - Human Toxicity Potential (HTP inf.) [kg DCB-Equiv.]; MAETP - Marine Aquatic Ecotoxicity Pot. (MAETP inf.) [kg DCB-Equiv.]; ODP - Ozone Layer Depletion Potential (ODP, steady state) [kg R11-Equiv.]; POCP - Photochem. Ozone Creation Potential (POCP) [kg EtheneEquiv.]; TETP - Terrestric Ecotoxicity Potential (TETP inf.) [kg DCB-Equiv.]

Figure 8. Contribution to environmental impact categories of operational steps of conventional and zero-joint edgebanding according to impact categories of CML 2001 (April 2015) impact assessment methodology

According to our examination (Figure 8), the following operational steps in the edgebanding technologies demonstrated considerable environmental impacts: 
- Operational steps marked with the number 1. This is due to the electrical energy intake, meaning an extra energy demand compared to the other steps in the case of both alternatives. There is a strong indicator of this as regards the impact categories.

- Operational steps marked with the number 3. In the case of conventional technology, the step of "Melting, adding EVA granulate and applying glue + pressing the edgebanding onto the workpiece edge (bonds the edge banding to the substrate)" while in the zero-joint technology, the step of "Pressing the edgebanding onto the workpiece edge (bonds the edge banding to the substrate)" had higher energy demand compared to the others.

- Operational steps marked with the number 4. We have higher energy demand here in our model as well due to the extra energy demand of the compressor in addition to the energy demand of "End-cutting banding material" in both the conventional and the zerojoint technology.

- Operational steps marked with the number 10. In both alternatives, the extra energy demand of heat transfer of colour correction need to be counted.

Calculation of the primary energy demand of the technologies is a built-in module in the $\mathrm{GaBi}$ Professional LCA software as well. Figure 9 illustrates the primary energy demand of the examined edging technologies. Life-cycle contribution rate developed as $47 \%$ conventional - 53\% zero-joint according to the model of energy consumption.

The constructed life cycle models have the attribute that the usage of the renewable energy sources $(8.41 \%)$ is only a fraction of the non-renewable energy sources used in the manufacturing technologies. This demonstrates a high potential of environmental development.

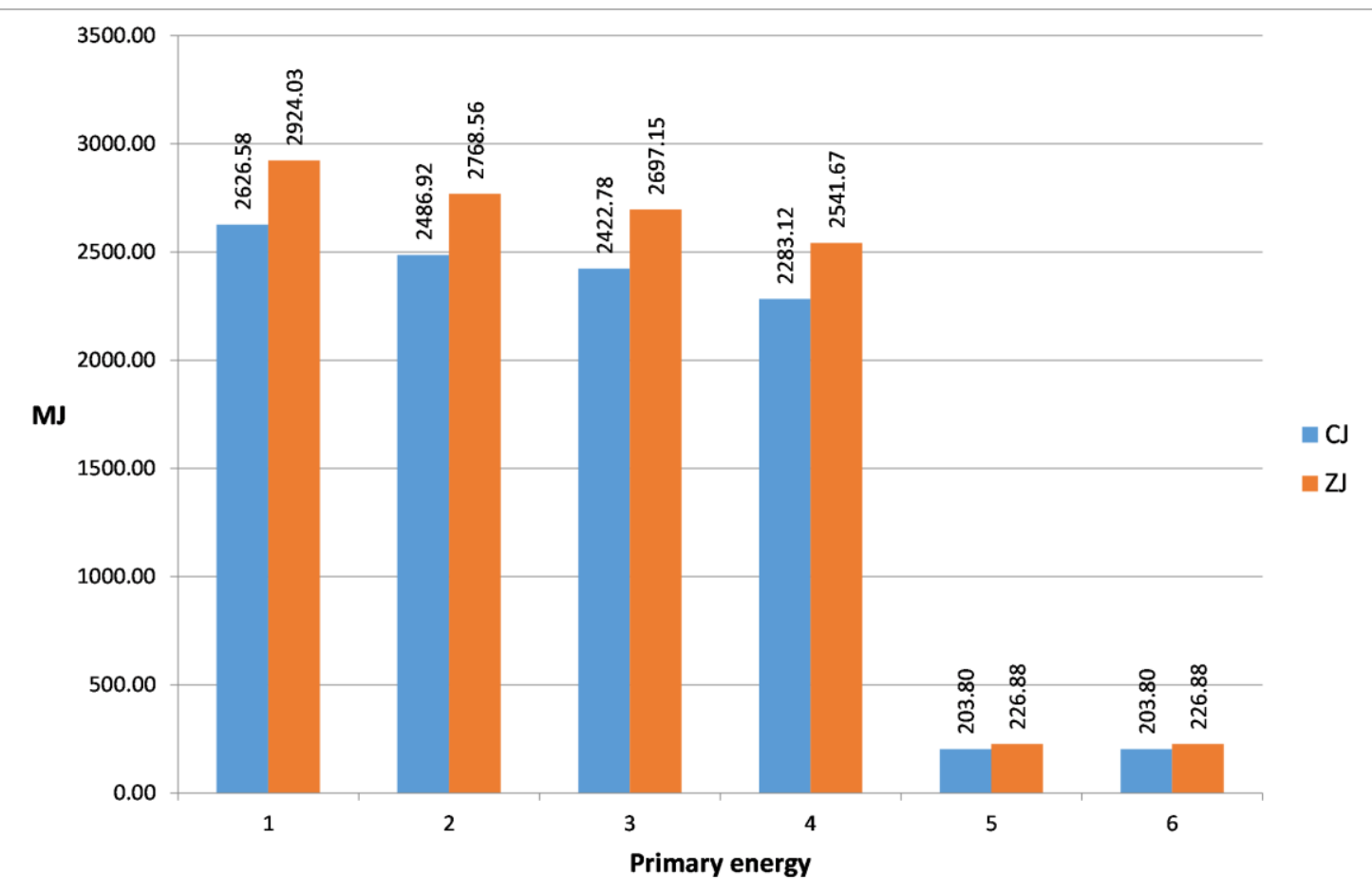

\footnotetext{
Abbreviations: Conventional (CJ) and Zero joints (ZJ) edgebanding;

1 - Primary energy demand from renewable, and non-renewable resources (gross cal. value) [MJ];

2 - Primary energy demand from renewable, and non-renewable resources (net cal. value) [MJ];

3 - Primary energy from non-renewable resources (gross cal. value) [MJ];

4 - Primary energy from non-renewable resources (net cal. value) [MJ];

5 - Primary energy from renewable resources (gross cal. value) [MJ];

6 - Primary energy from renewable resources (net cal. value) $[\mathrm{MJ}]$
}

Figure 9. Primer energy demand of edgebanding technologies [MJ] 


\section{CONCLUSIONS}

In our durability study, the edgebanded furniture fronts were the most sensible at the corners when exposed to moisture. Due to the high variations, the differences between conventional and zero joints were not statistically significant; however, there was a difference of two to three classes based on the assessment criteria for water resistance (Table 1). There was no consistency between the thickness swelling values of the two corners, since the conventional joints had higher values at the left corner. The edgebanded fronts exposed to moisture for a short period of time did not suffer significant deteriorations. In the case of steaming, the specimen' corners were affected the most and the thickness swelling of zero joints was significantly lower after the second and third treatment cycle. At $100 \mathrm{~mm}$ from the corners, the deterioration of edgebanding was considerably smaller and the visible differences between the joint types appeared after longer exposure.

The life cycle cost assessments revealed that zero-joint technology displays a 1.45 times surplus cost compared to conventional technology. Both technologies showed considerable costs of the edging material, the chipboard, and the electrical energy.

In our environmental study, we examined the environmental impact of edgebanding in woodwork by following the technological operation of a modern edgebander machine. In relation to conventional and the zero-joint edging technologies, according to all impact assessment methods, the life-cycle contribution rate was uniformly $47 \%$ conventional $-53 \%$ zero-joint by impact category. The higher indicator values of zero-joint method are due to the larger edge material consumption and the higher energy demand. The constructed life cycle models have the attribute that the usage of the renewable energy sources (8.41\%) is only a fraction of the non-renewable energy sources used in the manufacturing technologies. This demonstrates a high potential of environmental development.

Zero-joint technology appears to avoid the application of hot melt adhesive, but replacing these does not necessarily result in better environmental indicators. Nevertheless, zero-joint egdebanding does not just improve the appearance from an aesthetic point of view (invisible gluing joint line on the panels), but also exceeds the conventional edgebanding technology when durability aspects are considered.

Of course, the results obtained by the LCA examinations also depend on the nature of the model constructed in the analysing program and on how the electrical energy demand is distributed among the specific operational steps.

Not only are zero-joint edges aesthetically pleasing, but they also provide stronger, longerlasting edges and anti-bacterial benefits. The LCA method considers the environmental impact of the manufacturing technology, but it also addresses product durability. In the latter, the two technologies examined in this study demonstrated significant differences.

Acknowledgements: This article was made in frame of the "EFOP-3.6.1-16-2016-00018 Improving the role of research+development+innovation in the higher education through institutional developments assisting intelligent specialization in Sopron and Szombathely". This research was supported also by Competitiveness Operational Program 2014-2020 Priority Axis 1 - Research, Technological Development and Innovation (RDI) in support of Economic Competitiveness and Business Development Action 1.1.1 - Large CD infrastructures, Project type: Innovation clusters Project title: "Transylvanian Furniture Cluster - an innovative cluster of European interest" by the Sectoral Operational Programme Human Resources Development (SOP HRD), ID134378 financed from the European Social Fund and by the Romanian Government. 


\section{REFERENCES}

CML 2001 Methodology: GuinÉe, J.B. - GorRée, M. - HeiJungs, R. - HupPes, G. - Kleijn, R. Koning, A. De - Oers, L. VAn - Wegener SleeswiJK, A. - Suh, S. - Udo De Haes, H.A. BRUIJN, H. DE - DuIN, R. VAN - HUIJBREGTS, M.A.J.(2002): Handbook on life cycle assessment. Operational guide to the ISO standards. I: LCA in perspective. IIa: Guide. IIb: Operational annex. III: Scientific background. Kluwer Academic Publishers. Dordrecht. 692 p., https://www.universiteitleiden.nl/en/research/research-projects/science/cml-new-dutch-lca-guide

FAVA, J. A. - JONES, B. - DENISON, R. - CURRAN, M. A. - VigON, B. - SElKe, S. - BARNUM, J. (1994): A Technical Framework for Life-Cycle Assessment. SETAC Foundation for. Washington, DC. 134 p.

IOS (2017): IOS-TM-0002. Test method. Surface resistance - test methods. Inter IKEA Systems B.V. 1993-017. Sweden. 52 p.

ISO (2006a): ISO 14040:2006. Environmental management. Life cycle assessment. Principles and framework (ISO 14040:2006). International Organization for Standardization, Geneva, Switzerland. $20 \mathrm{p}$.

ISO (2006b): ISO 14044:2006. Environmental management. Life cycle assessment. Requirements and guidelines (ISO 14044:2006). International Organization for Standardization, Geneva, Switzerland. $46 \mathrm{p}$.

JiVKov, V (2002): Influence of Edge Banding on Banding Strength of End Corner Joints from $18 \mathrm{~mm}$ Particleboard. In: Conference Nabytok 2002 (CD - ROM). At: Technical University Zvolen. Volume: IV. Slovakia. October 2002, https://www.researchgate.net/publication/311391217

KoZÁK, J. (2016): Életciklus elemzés alkalmazása faipari élzáró gépen [Using Life Cycle Assessment method for an edgebanding machine]. University of Sopron, Sopron. 88 p. (in Hungarian), http://diploma.nyme.hu/id/eprint/2028

LAÁB, Á. (2021): Life Cycle Costing. ELTE, Budapest, Hungary. http://www.laabagnes.hu/wp-content/uploads/2008/04/life-_cycle_costing1.pdf

LipPKe, B. - Wilson, J. - PEREZ-GARCIA, J. -BOWYER J. -MeIL, J. (2004): CORRIM: Life-cycle environmental building materials. Forest Products Journal. 54 (6): 8-19.

https://www.researchgate.net/publication/238776944 CORRIM LifeCycle_Environmental_Performance_of_Renewable_Building_Materials

LIPPKE, B.R.- WILSON, J. - MEIL, J. - TAYLOR, A. (2019): Characterizing the importance of carbon stored in wood products. Society of Wood Science and Technology 42: 5-14.

https://www.researchgate.net/publication/228714657 Characterizing the importance of carbon _stored_in_wood_products

LugOSI, A. (1976): Faipari kézikönyv [Wood industry manual]. Müszaki Könyvkiadó [Technical Publishing], Budapest. 1095 p. (in Hungarian)

MERDZHANOV, V. (2018): Comparative study of tensile bond strength for melted EVA glue on particle boards with different edge banding materials. In: Proceedings of the $5^{\text {th }}$ International Conference on Processing Technologies for the Forest and Bio-based Products Industries (PTF BPI 2018). Germany. September 2018. 1-6.

https://www.researchgate.net/publication/328964901_Comparative_study_of_tensile_bond_stren gth_for_melted_EVA_glue_on_particle_boards_with_different_edge_banding_materials

MOLNÁRNÉ POSCH, P. (2002): Faipari kézikönyv II. [Wood industry manual II.] Faipari Tudományos Alapítvány [Wood Industry Science Foundation], Sopron. 461 p. (in Hungarian)

RECHNER, R. - JANSEN, I. - BEYER, E. (2009): Using lasers in edge banding. Adhesion Adhesives\&Sealants 6: 36-40., https://doi.org/10.1007/BF03250465

SAÇLI, C. (2015): The effect of time and edge banding type and thickness on the bending and tensile strength of melamine coated particleboard. In: Proceedings of the $27^{\text {th }}$ International Conference Research for Furniture Industry. Turkey. September 2015. 469-480.

TANKUT, A.N. - TANKUT, N. (2010): Evaluation the effects of edge banding type and thickness on the strength of corner joints in case-type furniture. Materials and Design 31 (6): 2956-2963. https://doi.org/10.1016/j.matdes.2009.12.022 
